\title{
日本語の文法および未知の認知単位の自動獲得のための一方法
}

\author{
横田 和章 ${ }^{\dagger}$ 亀田 弘之增䓫 博也 ${ }^{\dagger}$
}

筆者らは, コーパスに基づいて形態素を基本とした日本語文法を自動獲得する方法を 既に提案している. 本論文は，この方法における処理単位として，形態素の代わりに より長い単位—認知単位—を用いた新しい方法を提案するものである。認知単位 は, 人間を被験者とした知覚実験の結果から得られた人間の文解析の単位である。こ うした，形態素より長い単位を解析に用いることにより，構文解析における経路数を 抑えることができる。しかし，単純に認知単位を辞書に登録して用いるだけでは，未 知認知単位の出現確率が高まり, 結果として文解析の正解率が低下する。この現象を 抑えるため, 既知認知単位から未知認知単位を推定する新しい方法を更に取り入れた. この方法で天気概況文コーパスを処理し，得られた文法に基づき構文解析を行った結 果，形態素を処理単位とした解析に比べ高い処理効率を得ることができた.

キーワード： 構文解析，コーパス，文脈自由文法，シミュレーテッド・アニーリング法，認 知単位

\section{A method for automatic acquisition of Japanese grammar and unknown cognitive units}

\author{
KaZUAKi Yokota $^{\dagger}$, Hiroyuki Kameda $^{\dagger \dagger}$ and Hiroya Fujisaki ${ }^{\dagger}$
}

\begin{abstract}
A method for automatic acquisition of a grammar of Japanese based on morphemes from a corpus has already been proposed by the authors. This paper proposes a new method based on cognitive units, which have been experimentally found to be the units of the human process of sentence analysis, and have been known to be larger than morphemes. While the use of cognitive units can reduce the number of search paths, it may increase the number of unknown units and may degrade system performance. In order to cope with this problem, a method has been further introduced for identifying an unknown cognitive unit from known cognitive units. The proposed method was applied to the analysis of the 'weather-forecast' corpus, and the acquired grammar was used for parsing. The results indicated a higher processing efficiency for systems using cognitive units than for those using morphemes.
\end{abstract}

KeyWords: Syntactic analysis, Corpus, Context-free grammar, Method of simulated annealing, Cognitive unit

†東京理科大学基礎工学部電子応用工学科, Dept. of Applied Electronics, Faculty of Industrial Science and Technology, Science University of Tokyo

†† 東京工科大学工学部情報工学科, Dept. of Information Engineering, Faculty of Engineering, Tokyo Engineering University 


\section{1 まえがき}

自然言語の機械による処理方法の一つに，人間が与えた規則を用いて解析する方法がある. この方法では，一般に知識が複雑になるほど精密な解析ができるが，この複雑化に伴い知識獲 得が難しくなるため, 解析の対象となる話題を限定することがほぼ必須となる。この点におい て，人間により与えられた規則にのみ基づく解析は，限界にきているとの見方もある.

これに対して，自然言語に関する統計的情報を自然言語処理に利用する研究が盛んに行われ ている (宇津呂・松本 1995; 工藤・井上 1995; Jardino and Adda 1993). 人間によって与えら れた規則を元に解析を行う方法においても，規則の適用される確率を統計的に調べておくこと により良い結果が得られることが多く, 統計的な情報を自然言語処理に用いることは処理の効 率化に効果があるとみられる。

筆者らは既に，統計情報を自然言語処理に利用する方式の一つとして，コーパスに基づいて 日本語文法を自動獲得する方法を提案している (横田, 安部, 藤崎 1996). この獲得法は, まず構 文木情報の付加されたコーパスから多数の文の構文木を作成し, それぞれの節点にランダムに 非終端記号を割り当て，その後この割当てをエントロピーにより評価し，エントロピーが最小 となるようシミュレーテッド・アニーリング法により割り当てを変更するものである (Shannon 1951; 浅井 1965; Azencott 1992).

この方法を新聞記事の文法の獲得に適用した所, 得られた文法は終端記号と非終端記号との 間の置き換え規則のエントロピーが比較的高いことがわかった. 従って, この獲得法の単位と して形態素より長い単位—認知単位—を利用することによりエントロピーを下げれば，パー ザの動作効率を高めることができると期待される.

本論文ではこのような知見に基づき, 形態素より長い単位を人間による知覚実験の結果から 定義し, 文法の自動獲得に応用した, 新しい方法を提案する.

\section{2 文法の自動獲得法}

今, 図 1(a)のように例文と構文木が与えられていると仮定する.この場合, 文脈自由文法 における終端記号の集合は $T=\{$ 東, 日本,では,晴れて,い,ます $\}$ と書ける. 非終端記号の集合 を $N=\left\{n_{1}, n_{2}, n_{3}, n_{4}\right\}$, 初期記号を $n_{1}$ として, この構文木を同図 (b)のように変形し, 各節点 に非終端記号を割り当てたとする。すると, 各節点の上下関係から次の shift-reduce パーザの 規則を得ることができる(横田他 1996). 


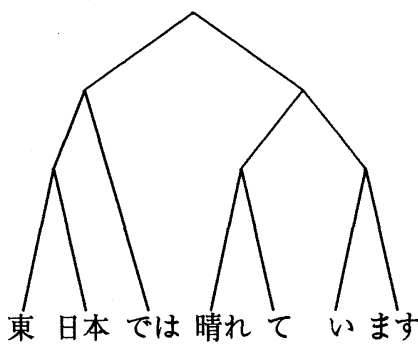

(a) 非終端記号割当てなし

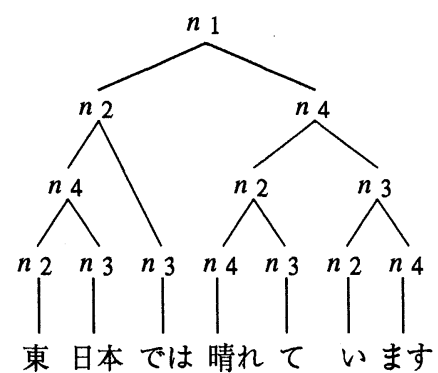

(b) 非終端記号割当て済み

図 1 構文木の各節点に対する非終端記号の割り当て

$$
\begin{aligned}
& R 1: \text { 東 } \rightarrow n_{2} \\
& R 2: \text { 日本 } \rightarrow n_{3} \\
& R 3: \text { では } \rightarrow n_{3} \\
& R 4: \text { 晴れ } \rightarrow n_{4} \\
& R 5: \text { て } \rightarrow n_{3} \\
& R 6: \text { い } \rightarrow n_{2} \\
& R 7: \text { ます } \rightarrow n_{4} \\
& R 8: n_{2}, n_{3} \rightarrow n_{4} \\
& R 9: n_{4}, n_{3} \rightarrow n_{2} \\
& R 10: n_{2}, n_{4} \rightarrow \text { shift } \\
& R 11: n_{4}, n_{3} \rightarrow n_{2} \\
& R 12: n_{2}, n_{2} \rightarrow \text { shift } \\
& R 13: n_{2}, n_{2} \rightarrow \text { shift } \\
& R 14: n_{2}, n_{4} \rightarrow n_{3} \\
& R 15: n_{2}, n_{3} \rightarrow n_{4} \\
& R 16: n_{2}, n_{4} \rightarrow n_{1}
\end{aligned}
$$

この規則の中には $R 10, R 14, R 16$ のように左辺が等しく右辺が異なるものが存在する。こ のような規則は, shift-reduceパーザの探索空間を広げ，処理速度を低下させる.

先の規則において左辺が $n_{i}, n_{j}$ の時, 右辺が $n_{k}$ となる条件つき確率を $P_{n_{i} n_{j}}\left(n_{k}\right)$, 右辺が shift となる条件つき確率を $P_{\mathrm{Shift}_{i} n_{j}}$ とする。同様に, 左辺が終端記号 $t_{i}$ の時, 右辺が $n_{j}$ と なる条件つき確率を $P_{t_{i}}\left(n_{j}\right)$ で表す。更に規則 $n_{i}, n_{j} \rightarrow n_{k}$ の出現確率を $P\left(n_{i}, n_{j}, n_{k}\right)$, 規則 $n_{i}, n_{j} \rightarrow$ shift の出現確率を $P_{\text {shift }}\left(n_{i}, n_{j}\right)$ とする. また規則 $t_{i} \rightarrow n_{j}$ の出現確率を $P\left(t_{i}, n_{j}\right)$ と する，すると，上記の shift-reduceパーザの規則はこれらの確率を用いて次のように書き直す ことができる. 


$$
\begin{aligned}
& P\left(\text { 東, } n_{2}\right)=0.06, \quad P_{\text {東 }}\left(n_{2}\right)=1.00 \\
& P\left(\text { 日本 }, n_{3}\right)=0.06, \quad P_{\text {日本 }}\left(n_{3}\right)=1.00 \\
& P\left(\text { では, } n_{3}\right)=0.06, \quad P_{\text {では }}\left(n_{3}\right)=1.00 \\
& P\left(\text { 晴れ }, n_{4}\right)=0.06, \quad P_{\text {晴れ }}\left(n_{4}\right)=1.00 \\
& P\left(\tau, n_{3}\right)=0.06, \quad P_{\tau}\left(n_{3}\right)=1.00 \\
& P\left(\text { い, } n_{2}\right)=0.06, \quad P_{\text {い }}\left(n_{2}\right)=1.00 \\
& P\left(\text { ます, } n_{4}\right)=0.06, \quad P_{\text {ます }}\left(n_{4}\right)=1.00 \\
& P\left(n_{2}, n_{3}, n_{4}\right)=0.13, \quad P_{n_{2} n_{3}}\left(n_{4}\right)=1.00 \\
& P\left(n_{4}, n_{3}, n_{2}\right)=0.13, \quad P_{n_{4} n_{3}}\left(n_{2}\right)=1.00 \\
& P_{\text {shift }}\left(n_{2}, n_{4}\right)=0.06, \quad P_{\text {shift }_{2} n_{4}}=0.33 \\
& P_{\text {shift }}\left(n_{2}, n_{2}\right)=0.13, \quad P_{\operatorname{shift}_{2} n_{2}}=1.00 \\
& P\left(n_{2}, n_{4}, n_{3}\right)=0.06, \quad P_{n_{2} n_{4}}\left(n_{3}\right)=0.33 \\
& P\left(n_{2}, n_{3}, n_{4}\right)=0.13, \quad P_{n_{2} n_{3}}\left(n_{4}\right)=1.00 \\
& P\left(n_{2}, n_{4}, n_{1}\right)=0.06, \quad P_{n_{2} n_{4}}\left(n_{1}\right)=0.33
\end{aligned}
$$

$R 1 \cdots R 16$ において左辺が等しく右辺が異なるような規則を減らすということは, 上記の条 件つき確率のすべてを 1 または 0 に近づけるということに対応する.これは更に次の (1) 式で 定義されるエントロピー $H$ を減少させることに等しい (Shannon 1951).

$$
\begin{aligned}
H= & \sum_{i, j} P_{\text {shift }}\left(n_{i}, n_{j}\right) \log P_{{\text {shift } n_{i} n_{j}}} \\
& -\sum_{i, j, k} P\left(n_{i}, n_{j}, n_{k}\right) \log P_{n_{i} n_{j}}\left(n_{k}\right) \\
& -\sum_{i, j} P\left(t_{i}, n_{j}\right) \log P_{t_{i}}\left(n_{j}\right)
\end{aligned}
$$

従って, 構文木の各節点に対する非終端記号の割当てを，Hが最小となるように変更すれば, shift-reduce パーザの動作に最適な規則を得ることができる。この最小化は組合わせ最適化問題 に対応する．この場合，組合せ空間にはいくつもの極小值が存在する.よって，この方法では シミュレーテッド・アニーリング法を用いて Hの最小化を行う (Azencott 1992).

こうして獲得した shift-reduceパーザの動作規則からは, 容易に文脈自由文法を作り出すこ とができる、すなわちこの方法は，文法を獲得する方法であるとみなせる．

また， $H を$ 用いて perplexity $Q$ を次のように計算できる.

$$
Q=\exp (H)
$$

$Q$ は物理的には，一つの左辺に対して平均いくつの右辺が存在するかを示す值となる.

新聞記事 7500 文を対象として, この方法により解析を行った結果, 左辺が形態素である規 則の条件つき生起確率 $P_{t_{i}}\left(n_{j}\right)$ は, 左辺が非終端記号 2 個の規則の条件つき生起確率 $P_{n_{i} n_{j}}\left(n_{k}\right)$ 
と比べて，值が小さくなることが示された (横田他 1996).

これは，一つの形態素が多数の用法を持っていることを示している．従って複数の形態素を 組合わせたより長い文字列を，この解析の単位として用いることにより， shift-reduce パーザの 解析効率をより高めることができると予想される。

\section{3 認知単位の知覚実験}

機械による文解析は，専ら形態素を単位として行われている (高橋 1986). しかし，人間で は果たしてどのような単位が用いられているのだろうか.これを確かめるため，知覚実験を 行った.

この実験では，コンピュータのディスプレイ上に 30 字程度の漢字かな混じり文を短時間表 示し, 被験者に口頭で読んでもらう。使用したディスプレイは，640×400 ピクセルの 15 インチ ディスプレイで, 被験者から約 $1 \mathrm{~m}$ の距離に配置してあり, $16 \times 16$ ピクセルの白いフォントで 文が提示される．被験者は成人男子大学生 4 名である.

まず，表示時間を $50 \mathrm{~ms}$ として 1 文を提示し，被験者に直ちに口頭で再生してもらう。文は 24 用意してあり，この実験を全文につき行なう．24 文の実験が終了すると，提示時間を $100 \mathrm{~ms}$ として再度 24 文の実験を行なう。ただし, 次に現れる文が予測できないよう文を提示する順序 を変える，表示時間を $50 \mathrm{~ms}$ 刻みで $1 \mathrm{~s}$ まで長くしながらこの実験を繰り返し, 表示時間と, 被 験者が読むことのできた文字数との関係を調べる.

画面上には，文の開始位置が常に示されており，被験者には提示の前に視点をその位置に移 動しておくように指示してある. 従って, 被験者は文を文頭から認識することになる. 被験者 にはあらかじめ文を覚えないよう伝えてあるが，実験を繰り返すうちに文頭付近を覚えること は避けられない。しかし, 提示時間は徐々に長くなるため, 被験者が再生できた文字列の末尾 付近については認識経験が少なく，記憶による影響は小さい.

実験結果を図 2 に示す。この例では,「この問題は解決ずみというつもりなのかもしれないが 私はそうは思わない.」という文を表示している. 結果は図のような階段状になり, 人間が文字 単位で文を処理しているのではないことは明らかである。また，読めた部分の最後に着目する と，それはすべて文節境界となりうる形態素で終っている. 更に, 「…というつもり」や「‥か もしれないが」などのように，複数の文節にまたがる句が一度に検出されているケースもある。 従つて，人間は文節よりも長い句を一度に検出していることが分かる。「…は」,「ㄴ..してる」， 「‥というつもり」,「‥かもしれないが」のように，それだけでは意味をなさず，先行する句 の後について補助的な意味を表すような句は, 先行する句の一部として先行する句とともに一 度に検出されている。この結果から，人間の場合，まずこのような補助的な句を含めた長い句 を一度に検出する処理を行い, この処理の後, 検出された長い句を組合わせて文を処理してい ると考えられる。 


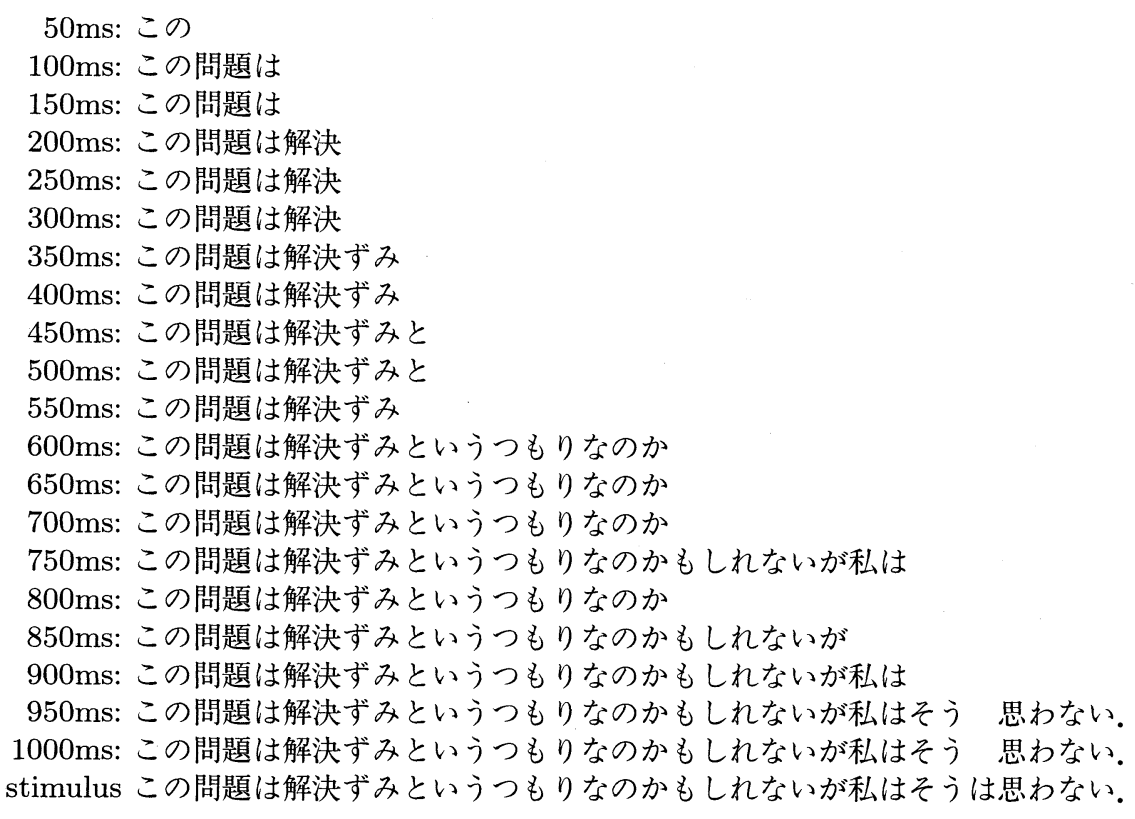

図 2 認知単位知覚実験の結果例

24 文の実験結果から，人間は，次のような句を一度に検出していることが分かった。

(1) 文節

（2）「〜かもしれない」などの慣用句

(3)「「している」などの補助用言を含んだ句

このような句を，本論文は認知単位と呼ぶことにする (横田・藤崎 1993).

\section{4 認知単位を用いた文法の獲得法}

\section{1 認知単位を用いた文法の獲得法の概要}

2 節で述べた獲得法により獲得した文法を用いる shift-reduce パーザは，認知単位の内部ま で係受けを調べるため，探索空間は膨大なものとなる。しかし，前節の考察から，人間におい ては, 認知単位の内部については, 通常解析は行っていないと考えられる。よって, 2 節の解析 方法の単位として，3 節で述べた認知単位を用いれば，探索空間は大きく狭まり検索効率は向 上すると考えられる。

本研究では，図 3 のように，認知単位を用いた構文木を作り文法を獲得するものとした. 


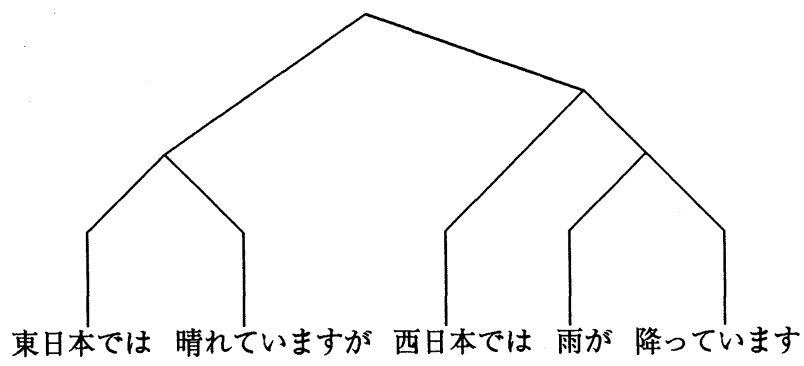

図 3 認知単位を用いた構文木

オホーツク海には，発達中の低気圧があって，北北東へ進んでいます。

一方，中国東北部には高気圧があって，ほとんど停滞しています.

西日本は晴れ，東日本はくもりで，北日本では所々で雨が降っています。

尚，北海道周辺海域と三陸沖では所々濃い霧の為見通しが悪くなっています.

日本近海は, 北海道東方海上から関東海域北部にかけて, シケています。

気温は，北海道，北陸，東海で，平年より 1 度高い他は，平年並か，1 度から 2 度低くなっています.

図 4 天気概況文の例

\section{2 天気概況文における機械処理用の認知単位}

この文法獲得を行うにあたり，NHKの気象通報の始めに放送される天気概況文 1000 文を， 構文木情報を含めて手入力し，コーパスとして用いた．使用した天気概況文の例を図 4 に示す.

人間の認知単位は知覚実験により得られるもので, 人間における認知単位をすべて明らかに して辞書を作成するためには膨大な知覚実験が必要となる，従って，本研究では簡単のため, 人間同様と思われる単位を新たに定義し，機械処理用の認知単位として解析に利用することと した，以下，本論文ではこの機械処理用の認知単位を，単に認知単位と呼ぶ。本論文では，天 気概況文における機械処理用の認知単位を次のように定義する.

\section{[天気概況文における機械処理用の認知単位の定義]}

$$
\text { 認知単位 }=\left\{\begin{array}{l}
\text { 自立語 } \\
\text { 自立語 }+ \text { 補助的な語 }
\end{array}\right.
$$

ただし，複合語は 1 つ自立語として扱う。また，活用する語については活用 語尾も含めて 1 つの自立語とする. 補助的な語は, 以下の形態素もしくはその組 み合わせとする。

$$
\text { 「が」,「は」,「です」,「ます」のような付属語列 }
$$

（2）継続，状態を示す「いる」「おる」

（3）状態を示す「なる」 


\section{3 認知単位を用いた文法の獲得実験}

前節に示したコーパスを用いて実際に文法の自動獲得を行なった。非終端記号数 $N_{n}=20,40,60,80$ における，シミュレーテッド・アニーリング法による文法獲得の様子 を図 5 に示す. $C_{p}$ は温度パラメータであり, 初期值を経験的に定め, 項比 0.98 の等比数列に 従い減少させた．各 $C_{p}$ について，各節点とも $2 N_{n}$ 回の非終端記号の更新を行った.この結果得 られた $Q$ の最終值を表 1 に示す．獲得の結果は，すべて $Q$ が 1.3 以下になった。これは動作規 則の左辺 1 つに対して，右辺が 1.3 以下となる規則が得られたことを示している.

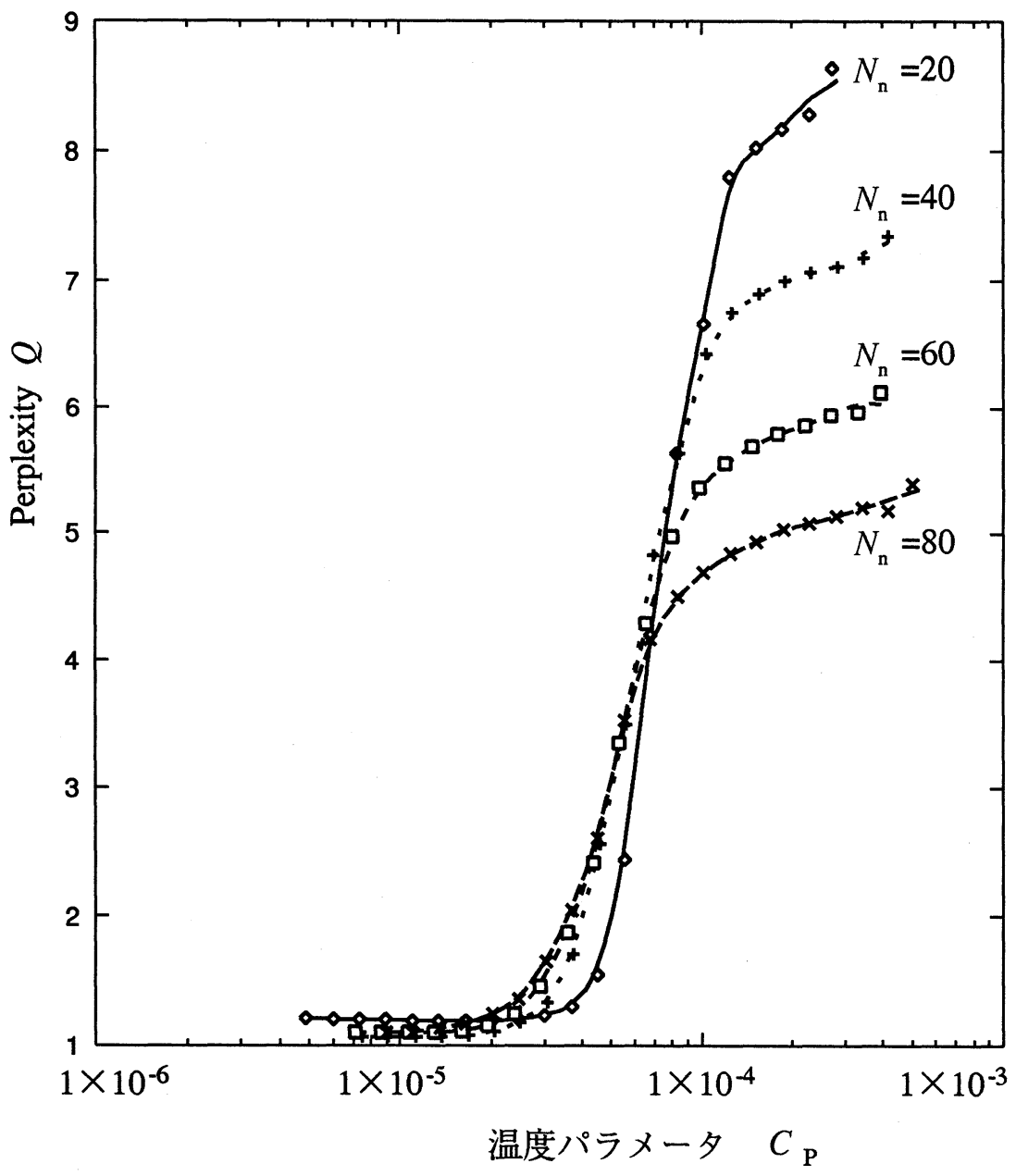

図 5 認知単位を用いた文法の自動獲得の様子 
表 1 獲得により得られた $Q$ の最終值

\begin{tabular}{c|c}
\hline \hline 非終端記号数 $N_{n}$ & 最終值 \\
\hline \hline 20 & 1.21 \\
40 & 1.06 \\
60 & 1.09 \\
80 & 1.10 \\
\hline \hline
\end{tabular}

\section{5 未知の認知単位の自動獲得法}

前節に述べた方法により，認知単位を基本とした文法を獲得することができる，従って， コーパスに出現した認知単位のすべてを辞書に納めておけば，前節で獲得した動作規則に基づ いて構文解析を行うことができる。しかし，認知単位は形態素を複数組合わせたものであるた め, 認知単位の中には極めて出現率が低いものがいくつも存在し, これらの認知単位は限られ たコーパス中においては，一度も出現しない可能性がある．従って収録文数が限られたコーパ スでは, 形態素を単位とした解析法よりも, 認知単位を単位とした解析法の方が未知語の比率 が高くなる。このようなコーパスの場合， 2 節の方法の単位として単に認知単位を用いただけ では，未知の認知単位を含む文が解析不能となり，結果的に解析効率が低下する.

この現象を抑えるためには, 未知の認知単位に関する知識を, 既知の認知単位に関する知識 から推定する必要がある。

本研究ではこの推定を行うため，認知単位を，形態素を基本とする状態遷移図で表現でき ると仮定する。すると，例えば「東日本では」という認知単位が「東」「「日本」，「では」とい う 3 つの形態素からなり, shift-reduce パーザの動作規則または文脈自由文法の生成規則によっ て，非終端記号 $n_{1}$ に置き換え可能であるとすると，この認知単位を図 6 のように，鿵れ状態 $u_{1} \ldots u_{4}$ を持つ状態遷移図モデルで表現し，取り扱うことができる.

同図における各状態に対して更に， $u_{1}$ を初期状態， $u_{2} ， u_{3}$ を中間状態， $u_{4}$ を受理状態と呼ぶ

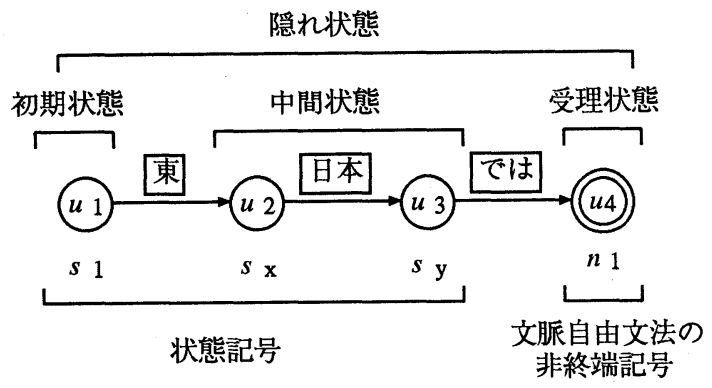

図 6 認知単位の状態遷移図モデル 
ことにし，この受理状態 $u_{4}$ が非終端記号 $n_{1}$ に対応しているものと考える.

コーパスに出現するすべての認知単位に対しこのモデルを適用し，各認知単位についてすべ て異なる隠れ状態 $u_{i}$ を生成すると，おびただしい数の隐れ状態が必要となる。このため，隠れ 状態の総数 $N_{u}$ より小さい $N_{s}$ を考え， $u_{1}$ のような初期状態を初期状態記号 $s_{1}$ に写像し， $u_{2}, u_{3}$ のような中間状態を中間状態記号 $s_{2} \ldots s_{N_{s}}$ のいずれかに写像する写像 $s_{y}=T_{u s}\left(u_{x}\right)$ を考え, 状 態を統一化する.

写像 $T_{u s}$ を決めると, コーパスより, 状態 $s_{i}$ から単語 $w_{j}$ を通って $s_{k}$ に移る確率 $P_{s}\left(s_{i}, w_{j}, s_{k}\right)$ と条件つき確率 $P_{s s_{i}}\left(w_{j}, s_{k}\right)$ を調べることができる．同様に状態 $s_{i}$ から単語 $w_{j}$ を通って $n_{k}$ に 移る確率 $P_{s}\left(s_{i}, w_{j}, n_{k}\right)$ と条件つき確率 $P_{s s_{i}}\left(w_{j}, n_{k}\right)$ も調べることができる.

これらの確率を用いて，状態遷移図のエントロピーは次のように表現される。

$$
\begin{aligned}
H_{s}= & -\sum_{i, j, k} P_{s}\left(s_{i}, w_{j}, s_{k}\right) \log P_{s s_{i}}\left(w_{j}, s_{k}\right) \\
& -\sum_{i, j, k} P_{s}\left(s_{i}, w_{j}, n_{k}\right) \log P_{s s_{i}}\left(w_{j}, n_{k}\right)
\end{aligned}
$$

このエントロピー $H_{s}$ を用いて, 状態遷移図における平均分岐数は次のように求まる.

$$
Q_{s}=\exp \left(H_{s}\right)
$$

$Q_{s}$ は物理的には，一つの状態から平均いくつの枝が出ているかを示している.

この方法で得られた状態遷移図を用いて，有限オートマトンで認知単位を検出するとすれ ば，この分岐数 $Q_{s}$ が小さい程オートマトンの決定性が高まり，動作が効率的になる.

$Q_{s}$ が最小となるよう $T_{u s}$ を求める問題は, 組合わせ最適化問題となる。この組合わせ空間に はやはり多数の極小值が存在するため，本研究ではシミュレーテッド・アニーリング法により $Q_{s}$ を最小化する。

$T_{u s}$ による状態の統一化により，ある認知単位に関する状態遷移図と，その認知単位に近い 用法を持つ別の認知単位に関する状態遷移図は交差する。この交差により, 認知単位に関する知 識は統一化され，未知の認知単位も受理できるようになる，従って，こうして得な状態遷移図 は未知の認知単位を含めた状態遷移図となる， $T_{u s}$ の最適化は，エントロピー $H_{s}$ を基準として この交差を最適化することになる。本研究では，この最適化により未知の認知単位に関する状 態遷移図も最適化されると仮定し, 最適化により得た状態遷移図に基づき認知単位を受理する.

このように形態素を基本とした状態遷移図を用いる方法では，最終的には辞書としては形態 素の辞書を持つことになる。しかし, 有限オートマトンによる解析は, shift-reduceパーザのよ うなより高次の解析方法に比べて動作が直線的であるため一般に高速である. 従って, 認知単 位内の解析に状態遷移図と有限オートマトンを用いる方法は, 文全体を shift-reduce パーザで 処理する方法に比べ高速となる利点がある. 


\section{6 未知の認知単位の自動獲得実験}

4 節で獲得した認知単位に関する知識に基づき，5節で述べた方法により未知の認知単位も 含めた状態遷移困を獲得する実験を行った，状態記号数 $N_{u}$ は 20 とした．この獲得の様子を困 7 に示す。この結果, 最終的に得られた $Q_{s}$ はほぼ 9 程度となった. $Q_{s}$ の最終值を表 2 に示す.

非終端記号数 $N_{n}=20$ として獲得した場合の，状態遷移図における遷移確率の高い枝の一 部を表 3 に示す.

状態遷移図の獲得により，形態素は自動的にクラスタリングされるが，このクラスタリング は人間のクラスタリングに類似していることが分かる.

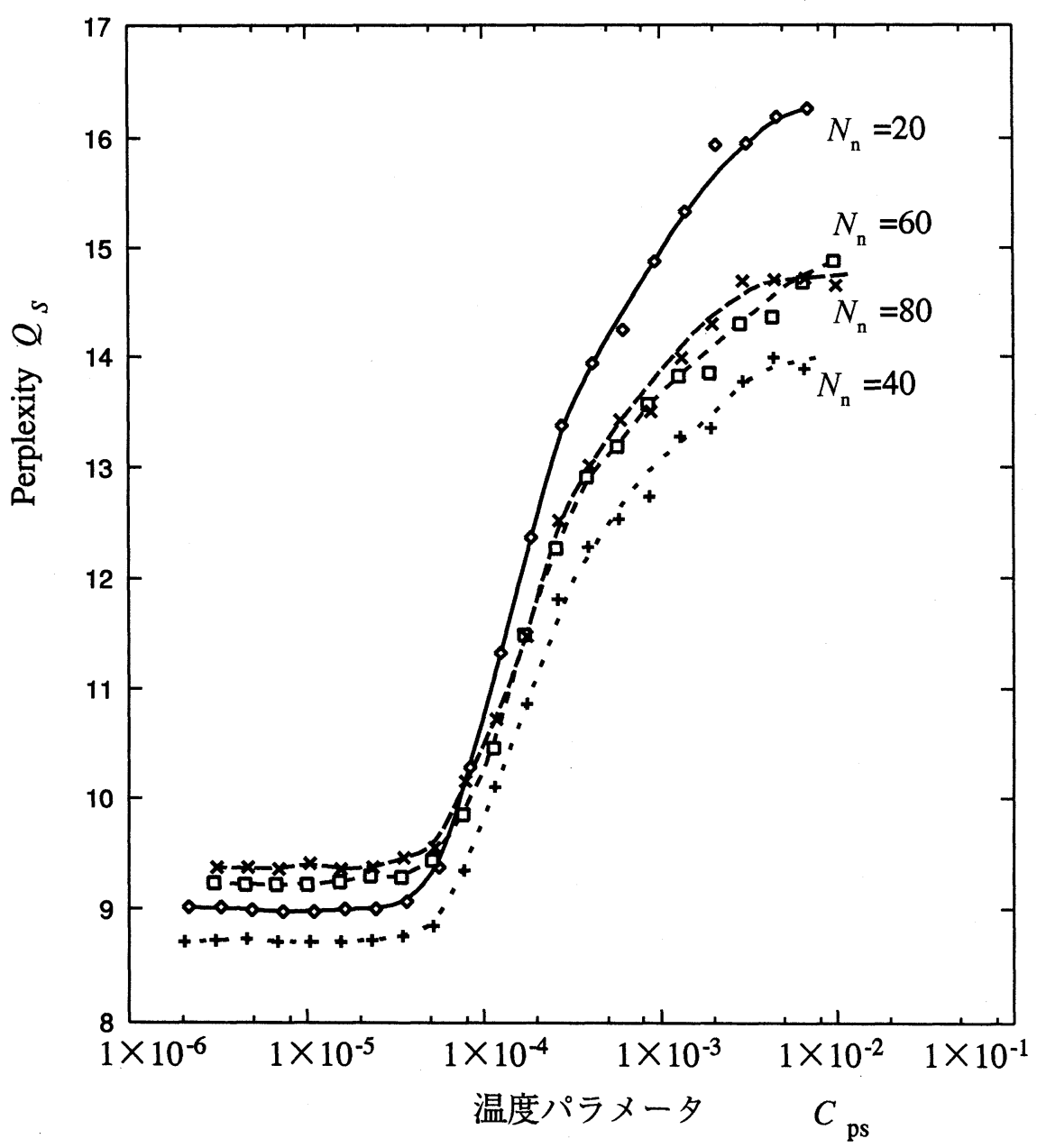

図 7 認知単位を表現する状態遷移図の獲得 
表 2 獲得により得られた $Q_{s}$ の最終值

\begin{tabular}{c|c}
\hline \hline 非終端記号数 $N_{n}$ & 最終值 \\
\hline \hline 20 & 9.02 \\
40 & 8.71 \\
60 & 9.23 \\
80 & 9.36 \\
\hline \hline
\end{tabular}

表 3 獲得により得られた状態遷移表 (部分)

\begin{tabular}{|c|c|c|c|c|}
\hline 前状態 & 次状態 & \multicolumn{3}{|c|}{ 主な形態素 } \\
\hline \multirow[t]{30}{*}{1} & $\overline{2}$ & 一部 & 西 & 北 \\
\hline & 3 & シケて & 進んで & 停滞して \\
\hline & 4 & 父島 & 別 & 霧 \\
\hline & 5 & 移動して & 降って & 晴れて \\
\hline & 6 & 6 & 他 & \\
\hline & 7 & 黄海 & 気温 & 三陸沖 \\
\hline & 8 & 1 & 2 & 3 \\
\hline & 9 & 千島 & 日本 & 発達中 \\
\hline & 10 & 前線 & 東北 & 平年並 \\
\hline & 11 & 低気圧 & & \\
\hline & 12 & 悪く & 高く & 大シケと \\
\hline & 13 & サハリン & 沖縄 & 九州 \\
\hline & 14 & かけて & 西日本 & 南 \\
\hline & 15 & 九州 & オホーツク海 & 沖縄 \\
\hline & 16 & 見通し & 高気圧 & 波 \\
\hline & 17 & 東 & 東シ十海 & 東北東 \\
\hline & 18 & 沖縄 & 関東 & 東海 \\
\hline & 19 & シケて & 見込み & 中 \\
\hline & 20 & 平年 & & \\
\hline & $n_{2}$ & 一方 & 尚 & 又 \\
\hline & $n_{4}$ & ため & 為 & \\
\hline & $n_{5}$ & 共に & 所々 & 伴った \\
\hline & $n_{6}$ & かけて & 高い & \\
\hline & $n_{7}$ & あって & & \\
\hline & $n_{10}$ & あって & 大体 & 低い \\
\hline & $n_{13}$ & ほとんど & ほほ & 大体 \\
\hline & $n_{15}$ & 濃い & 発達した & ほとんど \\
\hline & $n_{16}$ & あって & & \\
\hline & $n_{18}$ & 次第に & 伴った & \\
\hline & $n_{19}$ & 今後 & 日本海 & \\
\hline
\end{tabular}

\section{7 獲得した知識に基づく構文解析}

以上の議論に基づき，(A) 形態素を基本として文法を獲得する方法，(B) 認知単位を基本と して文法を獲得し，認知単位をそのまま辞書に登録する方法，(C) 認知単位を基本として文法 を獲得し，認知単位を受理する状態遷移図を獲得する方法の 3 つの評価を行った.

評価は，獲得した文法に基づき，別に用意した 100 文を構文解析することによって行った. 計算はSUN の SPARC Station 20 モデル 612 を用いた。この結果を表 4 に示す.

表中において正解率はこの結果, 最も確からしいと判断された構文木が, コーパスに与えら れている構文木と等しい確率を示す.

探索は best-first search 法を用いているため, 既存の知識では最終的に構文木が生成できな 
表 4 獲得した知識に基づく構文解析結果

\begin{tabular}{c|c|cc}
\hline \hline 方法 & 非終端記号数 $N_{n}$ [個] & 時間 [s] & 正解率 [\%] \\
\hline \hline (A) & 20 & 1156 & 47 \\
& 40 & 347 & 43 \\
& 60 & 181 & 44 \\
& 80 & 267 & 40 \\
\hline (B) & 20 & 1877 & 44 \\
& 40 & 3 & 42 \\
& 60 & 4 & 35 \\
& 80 & 4 & 38 \\
\hline (C) & 20 & 2799 & 49 \\
& 40 & 226 & 44 \\
& 60 & 95 & 44 \\
& 80 & 9 & 43 \\
\hline \hline
\end{tabular}

い文があると，その文の処理に極端に時間がかかる。その一方で，解に容易に到達できる場合 もあり，文によって処理時間のばらつきが大きい. 非終端記号 20 では，このように探索に時間 がかかる文が多く，(A)(B)(C) ともに長い時間を要している。特に認知単位を用いた $(\mathrm{B})$ およ び $(\mathrm{C})$ では，表 1 における $Q$ が，他に比べて大きく，この結果長い時間がかかっているものと 思われる. 従って, 認知単位を用いた方法では, 非終端記号 20 では十分に整理された文法が得 られないものと考えられる。

しかし，非終端記号数が 40 以上になると $(\mathrm{B})(\mathrm{C})$, 特に $(\mathrm{B})$ は，処理速度が著しく高速にな る.これは, 認知単位を用いる方が, 構文木を構成する葉の候補の数が少ないため, 構文解析 での探索経路が少なくなることに起因する.

正解率でみると，(C) が最も良く，ついで $(\mathrm{A})(\mathrm{B})$ の順となっている. (B) が $(\mathrm{A})$ に比べて 劣るのは未知認知単位があるためであると考えられる。(C) において未知認知単位の自動獲得 が有効に機能しているのが分かる.

\section{8 むすび}

以上，認知単位を用いた文法の自動獲得法を提案した。認知単位を基本とした文法を用いる 解析法は, 形態素を基本とした文法を用いる解析法に比べ効率が高い. 一般に自然言語の文法 は多重折込み要素が存在するため, 文全体の解析に状態遷移図を利用するのは適当ではないが, 認知単位のような狭い範囲に状態遷移図を利用するのは有効であることが明らかとなった.

本方法以外の文解析方法においても，認知単位を利用することにより処理を効率化すること ができるものと考えられる.

\section{謝辞}

本研究を進めるにあたり，データ入力やプログラミングに協力してくれた東京理科大学藤崎 研究室の阿部賢司氏並びに青島直哉氏に深く感謝する. 


\section{参考文献}

浅井清郎 (1965). “日本語の Entropy について.”計量国語学, 34, 4-7.

Azencott, R. (1992). Sequential simulated annealing: speed of convergence and acceleration techniques. John Wiley \& Sons, inc.

Jardino, M. and Adda, G. (1993). "Automatic Word Classification using Simulated Annealing." In Proceedings of IEEE ICASSP, Vol. 2, pp. 41-44.

工藤育男・井上直己 (1995). “コーパスに基づく共起知識の獲得とその応用.” 人口知能誌, 10 (2), 205-212.

Shannon, C. E. (1951). "Prediction and Entropy of Printed English." The Bell System Technical Journal, 30 (1), 50-64.

高橋延匡 (1986). 日本語情報処理. 近代科学社.

宇津呂武仁・松本裕治 (1995). “コーパスを用いた言語知識の獲得.” 人口知能誌, 10 (2), 197-204.

横田和章・藤崎博也 (1993). “認知単位を基本とする文解析手法の検討.”平 6 情処前期全大, $\mathbf{3}$, 69-70.

横田和章, 安部賢二, 藤崎博也 (1996). “コーパスに基づく日本語文法の自動獲得.”平 8 言語処 理学会年次大会, 169-172.

\section{略歴}

横田 和章: 1989 年東京理科大学基礎工学部電子応用工学科卒業. 1993 年同大 学大学院修士課程了. 1996 年同大学大学院博士後期課程了. 現在，(株) 東芝 青梅工場所属.

奄田 弘之： 1982 年東京大学工学部電子工学科卒業. 1984 年同大学大学院修士 課程了. 1987 年同大学大学院博士課程了. 工学博士. 現在, 東京工科大学工 学部助教授. 自然言語処理の研究に従事.

藤崎 博也： 1954 年東京大学工学部電気工学科卒業. MIT $-K T H(1958-1961)$. 1962 年東京大学大学院博士課程了. 工学博士. 同年東京大学工学部専任講 師. 1963 年同助教授. 1973 年同教授. 1991 年東京大学名誉教授，東京理科 大学基礎工学部教授. 音声生成・知覚・情報処理, 自然言語処理等の研究に 従事。昭和 38 年度電気通信学会稲田賞, 昭和 42 年度同学会論文賞, 昭和 42 年度電気学会論文賞，昭和 47 年度電子通信学会業績賞，1987 年 IEEE 音響・ 音声・信号処理学会功績賞, 1988 年米国音響学会特別功績賞, 1989 年東京 都科学技術功労表彰受賞. 